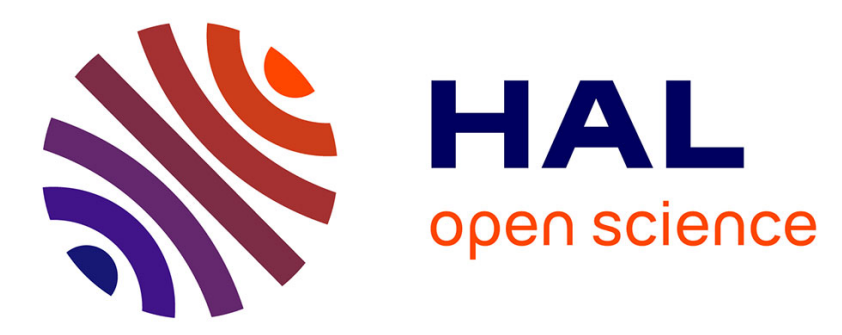

\title{
Formation of molybdenum nitrides by ammonia nitridation of Mo powder and sheet
}

Vera Ucakar, François Cheviré, Franck Tessier, Natalya Krendelsberger, Roger Marchand, Walter Lengauer

\section{- To cite this version:}

Vera Ucakar, François Cheviré, Franck Tessier, Natalya Krendelsberger, Roger Marchand, et al.. Formation of molybdenum nitrides by ammonia nitridation of Mo powder and sheet. Defect and Diffusion Forum, 2001, 194-199, pp.1607-1612. 10.4028/www.scientific.net/DDF.194-199.1607 . hal01201799

\section{HAL Id: hal-01201799 \\ https://hal.science/hal-01201799}

Submitted on 22 Sep 2015

HAL is a multi-disciplinary open access archive for the deposit and dissemination of scientific research documents, whether they are published or not. The documents may come from teaching and research institutions in France or abroad, or from public or private research centers.
L'archive ouverte pluridisciplinaire HAL, est destinée au dépôt et à la diffusion de documents scientifiques de niveau recherche, publiés ou non, émanant des établissements d'enseignement et de recherche français ou étrangers, des laboratoires publics ou privés. 


\title{
Formation of molybdenum nitrides by ammonia nitridation of Mo powder and sheet
}

\author{
V. Ucakar ${ }^{1}$, F. Cheviré ${ }^{1}$, F. Tessier ${ }^{2}$, N. Krendelsberger ${ }^{3}$, R. Marchand ${ }^{2}$, \\ W. Lengauer ${ }^{1}$ \\ ${ }^{1}$ Institute for Chemical Technology of Inorganic Materials, Vienna University of \\ Technology, Getreidemarkt 9/161, A-1060 VIENNA, Austria, www.tuwien.ac.at/physmet \\ ${ }^{2}$ Laboratoire "Verres et Céramiques", Université de Rennes I, \\ av. Général Leclerc, F-35042, RENNES, France \\ ${ }^{3}$ Institute of Physical Chemistry, University of Vienna, \\ Währingerstrasse 42, A-1090, VIENNA, Austria
}

Keywords: molybdenum nitrides, ammonia nitridation, diffusion, hardness

\begin{abstract}
The formation of molybdenum nitrides was investigated at temperatures up to $1200^{\circ} \mathrm{C}$ in flowing ammonia with various flow rates and reaction times. The products were characterised by XRD, chemical analysis, metallography and EPMA. The phases $\gamma-\mathrm{MoN}_{1-\mathrm{x}}$ and $\delta$ $\mathrm{MoN}$ formed at temperatures above $600^{\circ} \mathrm{C}$ only at high flow rates of about $201 / \mathrm{h}$. If the flow decreases even powders did not show the $\delta-\mathrm{MoN}$ phase. $\beta-\mathrm{Mo}_{2} \mathrm{~N}$ was observed by XRD in both, powder samples and compact samples. While a distinct and dense $\gamma-\mathrm{MoN}_{1-x}$ layer formed, the layer of $\delta$-MoN was too thin to be detected by metallography of the wedge-type samples and could only be observed by XRD of the surface. Microhardness of a $\gamma-\mathrm{MoN}_{1-\mathrm{x}}$ diffusion layer revealed at $1000^{\circ} \mathrm{C}$ was measured as a function of composition. The homogeneity range of $\gamma-\mathrm{MoN}_{1-\mathrm{x}}$ at around $900-1000^{\circ} \mathrm{C}$ was determined by EPMA. The diffusivity of nitrogen in $\gamma-\mathrm{MoN}_{1-\mathrm{x}}$ at $1000^{\circ} \mathrm{C}$ was calculated.
\end{abstract}

\section{INTRODUCTION}

Molybdenum nitrides are interesting as materials with high hardness and superconductors with critical temperatures between 5 and $14.9 \mathrm{~K}$ [1]. Details on the formation temperature, phase relationships and properties of molybdenum nitrides are still incompletely known. They have high nitrogen equilibrium pressures so that nitridation has to be performed in flowing ammonia unless high-pressure equipment is used. This can be made by using molybdenum compounds such as sulphides [2] or chlorides [3]. However, in order to study the in-diffusion of nitrogen into Mo metal the most straightforward technique is to use Mo sheet and powder as a starting material.

\section{EXPERIMENTAL}

The nitridation reactions were carried out in a horizontal open-flow system with Mo (powder or sheet and/or wedge) in a ceramic boat under the flow of $\mathrm{NH}_{3}$ (Fig. 1). The $\mathrm{NH}_{3}$ was passed through a separate tube into the reaction zone to prevent decomposition [3]. The nitriding conditions for the sheets and wedges are presented in Table 1. After the nitridation, a part of the samples were cooled down to room temperature under nitrogen atmosphere the other in $\mathrm{NH}_{3}$. 
Table 1

Conditions for the nitridation experiments

\begin{tabular}{|c|c|c|}
\hline $\begin{array}{c}\text { temperature } \\
{\left[{ }^{\circ} \mathbf{C}\right]}\end{array}$ & $\begin{array}{c}\mathbf{N H}_{\mathbf{3}} \text {-flow } \\
{[\mathbf{l} / \mathbf{h}]}\end{array}$ & $\begin{array}{c}\text { reaction time } \\
{[\mathbf{h}]}\end{array}$ \\
\hline 1200 & 10 & 40 \\
\hline 1050 & 7 & 20 \\
\hline 1000 & 20 & 15 and 37 \\
\hline 1000 & 40 & 15 \\
\hline 1000 & 10 & 40 \\
\hline 1000 & 7 & 20 \\
\hline 900 & 20 & $24,30,44$ and 72 \\
\hline 850 & 7 & 20 \\
\hline 781 & 8 & 40 \\
\hline 600 & 20 & 62 \\
\hline 300 & 20 & 47 \\
\hline
\end{tabular}

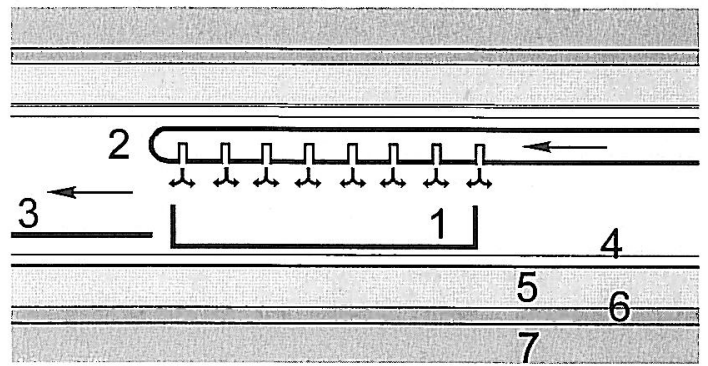

Fig. 1

Scheme of the nitridation furnace

1 ceramic boat; $2 \mathrm{NH}_{3}$-supply; 3 thermocouple; $4 \mathrm{SiO}_{2}$ tube; 5 tube with filament winding; 6 ceramic tube; 7 insulationwool

The nitrided samples were subjected to metallography, XRD, chemical analysis and EPMA. To detect thin layers and/or gradients in the microstructure at the outermost surface of the samples glancing angle XRD (GAXRD) was used to obtain depth-resolved information. Thereby the dependence of the penetration depth on the angle of incidence of the incoming beam is used. The microhardness of the $\gamma-\mathrm{MoN}_{1-\mathrm{x}}$ phase was measured as a function of composition from a diffusion layer obtained at $1000^{\circ} \mathrm{C}$ at a load of $5 \mathrm{~N}$.

\section{RESULTS}

By XRD analysis of the powder samples different molybdenum-nitride phases were found. Nitriding conditions, detected phases by XRD and results of the chemical analysis are given in Table 2. These experiments show that nitrogen diffusivity is such slow that even the powder particles on the order of ca. $10 \mu \mathrm{m}$ in diameter are not completely nitrided. The flow rate is also important at these relatively high temperatures because of ammonia decomposition. Thus, the higher the flow rate the higher the amount of undecomposed $\mathrm{NH}_{3}$ reaching the sample and the higher

Table 2

Nitriding conditions and phase analysis of molybdenum nitride powders

\begin{tabular}{|c|c|c|c|c|c|}
\hline \multirow{3}{*}{$\begin{array}{c}\begin{array}{c}\text { reaction } \\
\text { temperature } \\
{\left[{ }^{\circ} \mathrm{C}\right]}\end{array} \\
1000\end{array}$} & \multirow{3}{*}{$\begin{array}{c}\begin{array}{c}\mathrm{NH}_{3} \\
\text { flow rate } \\
\text { [1/h] }\end{array} \\
\sim 5\end{array}$} & \multirow{3}{*}{$\begin{array}{c}\begin{array}{c}\text { reaction } \\
\text { time } \\
\text { [h] }\end{array} \\
20\end{array}$} & \multirow{3}{*}{$\begin{array}{c}\text { detected } \\
\text { phases (XRD) } \\
\text { Mo, } \gamma-\mathrm{MoN}_{1-\mathrm{x}}, \\
\beta-\mathrm{Mo}_{2} \mathrm{~N}\end{array}$} & \multicolumn{2}{|c|}{$\begin{array}{c}\text { chemical analysis } \\
\text { [wt\%] }\end{array}$} \\
\hline & & & & $\mathbf{N}$ & 0 \\
\hline & & & & $\begin{array}{l}4.903 \\
4.941\end{array}$ & $\begin{array}{l}0.3861 \\
0.3108\end{array}$ \\
\hline 1000 & $\sim 7$ & 20 & $\begin{array}{c}\mathrm{Mo}, \gamma-\mathrm{MoN}_{1-\mathrm{x}} \\
\beta-\mathrm{Mo}_{2} \mathrm{~N}\end{array}$ & $\begin{array}{l}5.828 \\
5.869 \\
5.872\end{array}$ & $\begin{array}{l}0.3046 \\
0.3466 \\
0.2278\end{array}$ \\
\hline 1100 & $\sim 7$ & 20 & $\begin{array}{c}\mathrm{Mo}, \gamma-\mathrm{MoN}_{1-\mathrm{x}}, \\
\beta-\mathrm{Mo}_{2} \mathrm{~N}\end{array}$ & $\begin{array}{l}5.102 \\
5.231\end{array}$ & $\begin{array}{l}0.2341 \\
0.3409 \\
0.2300\end{array}$ \\
\hline
\end{tabular}


the nitrogen content of the product. If the temperature is increased to $1100^{\circ} \mathrm{C}$ the nitrogen content lowers (at the same experimental conditions) due to the higher nitrogen equilibrium pressure of the solid phase.

A typical microstructure of a molybdenum-nitrogen diffusion wedge is presented in Fig. 2. It shows a compact and well-adhering $\gamma-\mathrm{MoN}_{1-\mathrm{x}}$ layer at the outermost part and molybdenum in the core.

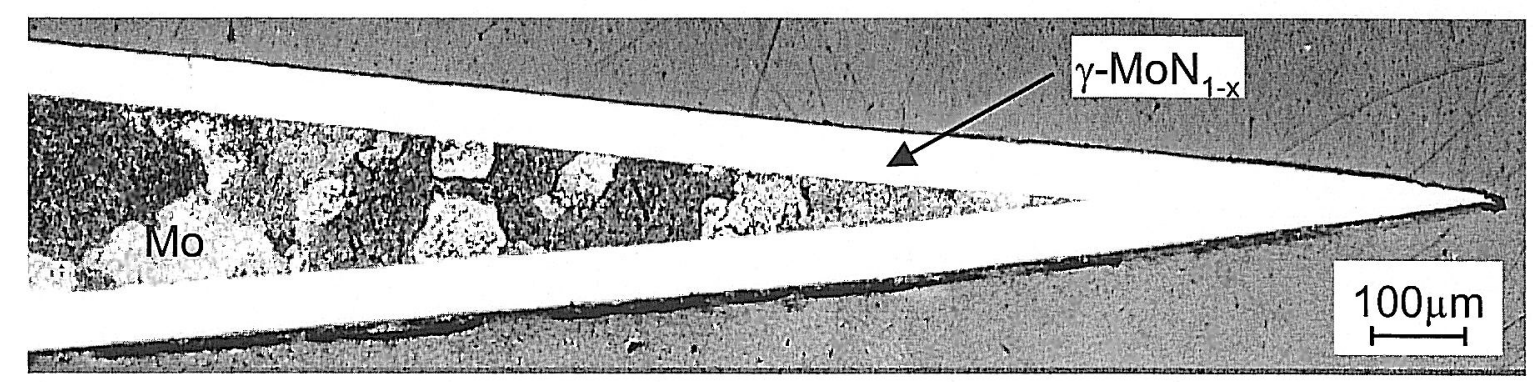

Fig. 2

Microstructure of a diffusion wedge, $\left(1000^{\circ} \mathrm{C} ; 201 / \mathrm{h} \mathrm{NH}_{3} ; 15 \mathrm{~h}\right)$

Perpendicular across the $\gamma-\mathrm{MoN}_{1-\mathrm{x}}$ layer there were few cracks which indicates stress between the $\gamma$ $\mathrm{MoN}_{1-\mathrm{x}}$ layer and the molybdenum core.

By XRD also $\delta$-MoN was found in most samples but these layers were too thin to be prepared and observed by metallography and therefore they are not visible in the optical microscope. In Fig. 3 two GAXRD patterns measured with different angles of incidence (which means different penetration depths) of a sample, showing $\delta-\mathrm{MoN}$ at the outermost surface, and $\gamma-\mathrm{MoN}_{1-\mathrm{x}}$ below is presented. It can be seen that the peaks belonging to the $\gamma-\mathrm{MoN}_{1-\mathrm{x}}$ phase are larger in the pattern which is measured using an angle of incidence of $10^{\circ}$ which means a greater penetration depth.

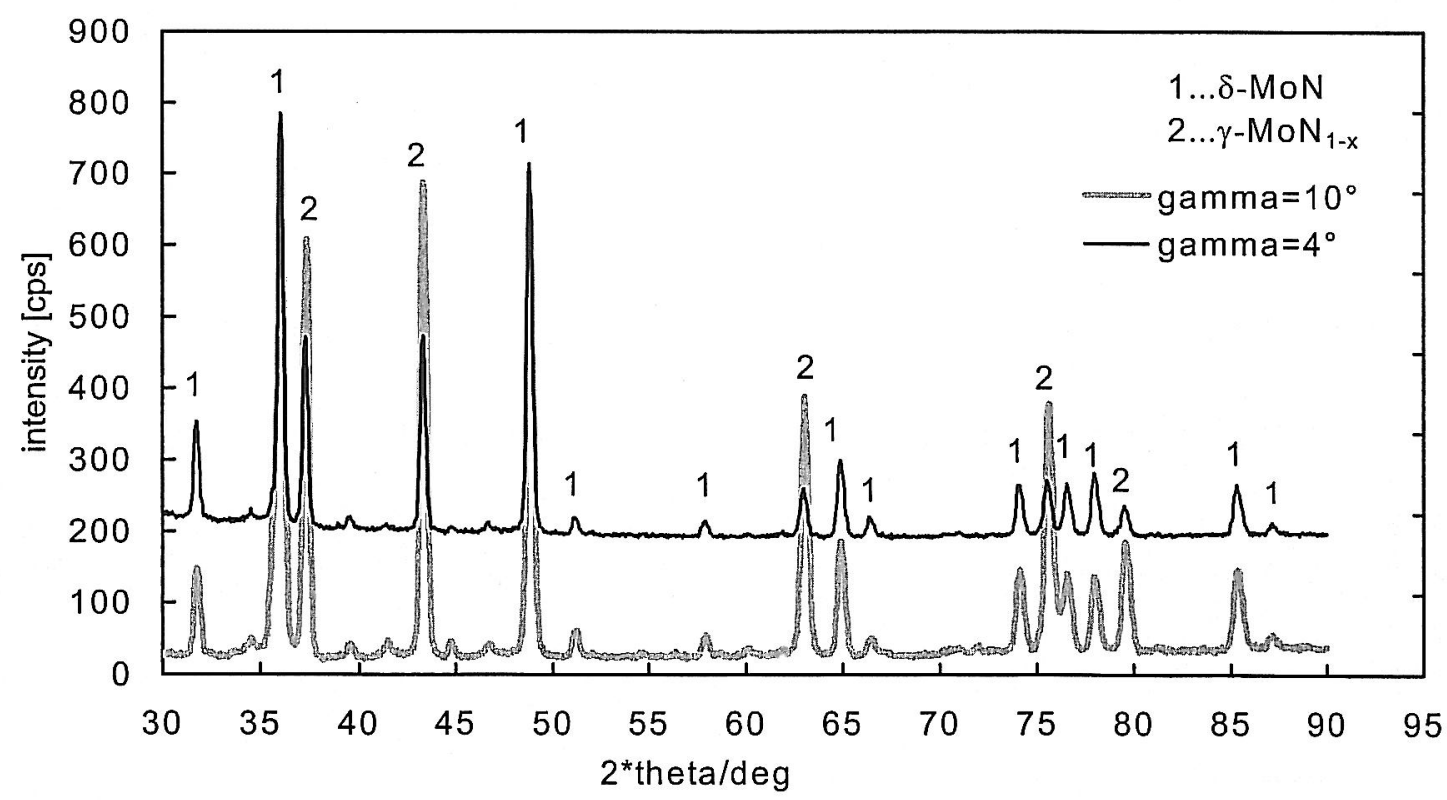

Fig. 3

GAXRD pattern of a nitrided Mo sheet; $\left(900^{\circ} \mathrm{C} ; 201 / \mathrm{h} \mathrm{NH} 3 ; 72 \mathrm{~h}\right)$

In one sheet sample an about $1 \mu \mathrm{m}$ thick $\beta-\mathrm{Mo}_{2} \mathrm{~N}$ layer was observed at the outermost surface (see Fig. 4). Below this layer an Mo layer was found which originally consisted of $\gamma-\mathrm{MoN}_{1-\mathrm{x}}$. The third layer indeed consisted of $\gamma-\mathrm{MoN}_{1-\mathrm{x}}$. Such a result was obtained if $\mathrm{N}_{2}$ was used upon cooling. 


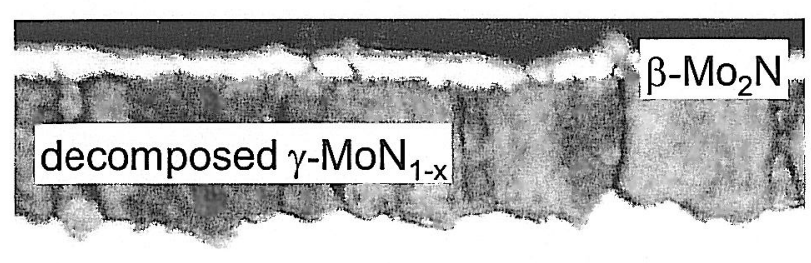

$\gamma-\mathrm{MoN}_{1-\mathrm{x}}$

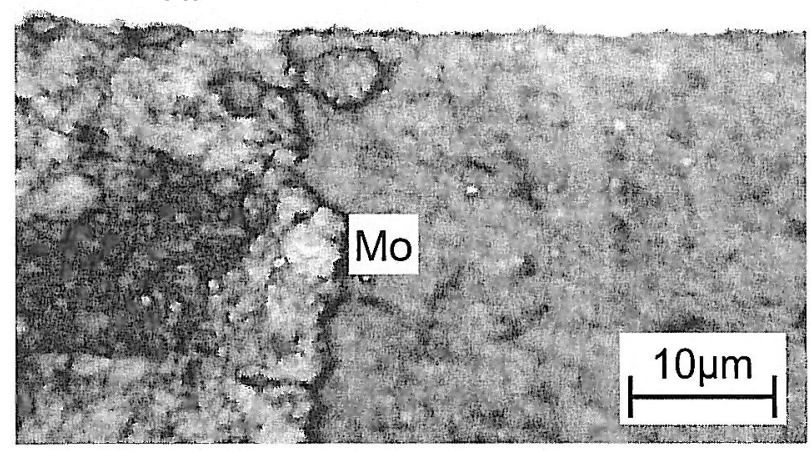

Fig. 4

Microstructure of the near surface area of a Mo-N diffusion couple; $1200^{\circ} \mathrm{C}, 101 / \mathrm{hNH}_{3}$, $40 \mathrm{~h}$
Obviously, nitrogen diffuses out of the sample because $\mathrm{N}_{2}$ has a lower nitriding potential than $\mathrm{NH}_{3}$. The reason why $\beta-\mathrm{Mo}_{2} \mathrm{~N}$ is formed upon this out-diffusion process can be explained by the lower nitrogen equilibrium pressure of this phase which is already achieved by the nitrogen atmosphere. To investigate the homogeneity range of the $\gamma-\mathrm{MoN}_{1-\mathrm{x}}$ phase EPMA scans were performed. These measurements were done for two different temperatures $\left(900^{\circ} \mathrm{C}\right.$ and $\left.1000^{\circ} \mathrm{C}\right)$. Fig. 6a presents an EPMA-scan along the nitrogen-diffusion path. From these scans the nitrogen concentration of the inner phase boundary was obtained. The nitrogen concentration of the nitrogen richer phase boundary was measured from scans along the symmetry plane of the wedge-type samples because the tip provides better analysis conditions as compared to the edge of the sample (see Fig. $6 b)$. The results are presented in Table 3 .

Fig. 5

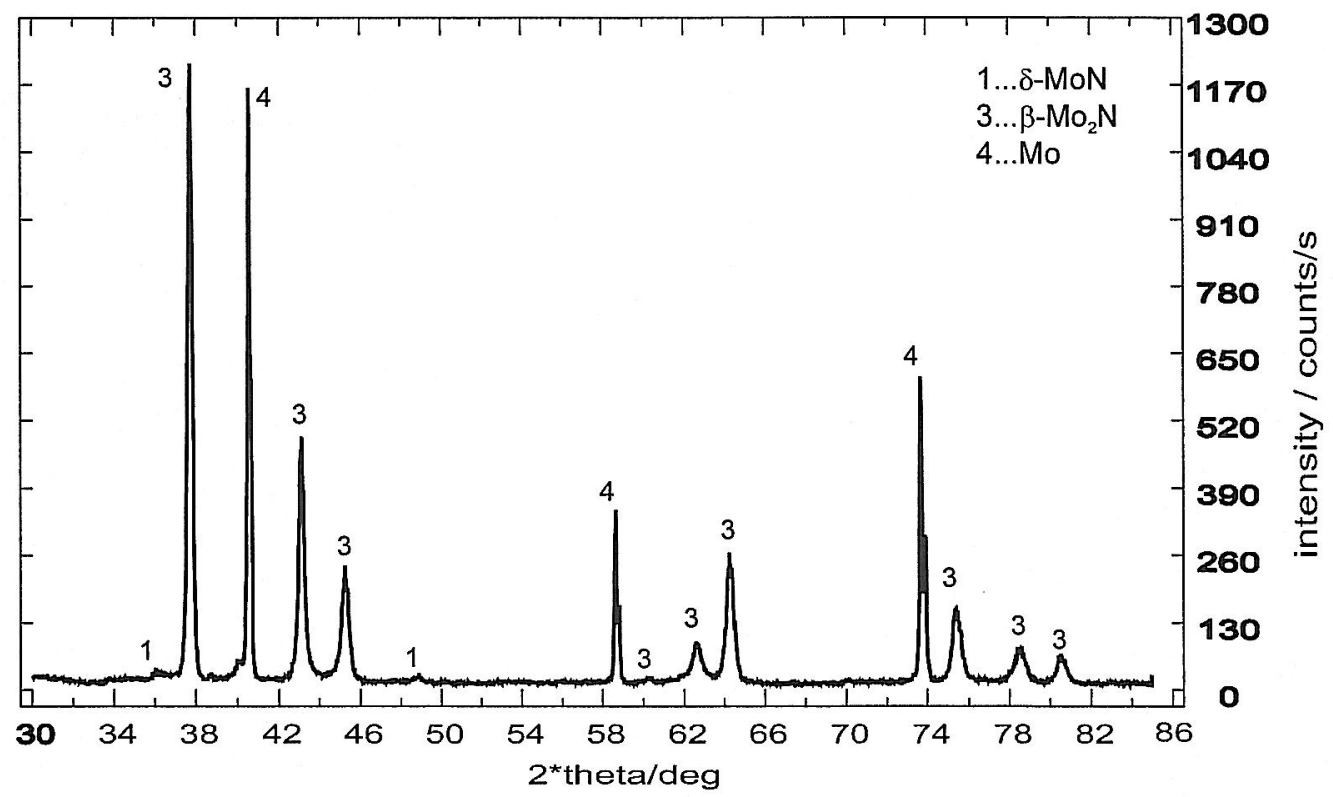

XRD pattern of a sample which shows $\beta-\mathrm{Mo}_{2} \mathrm{~N}$ at the outermost surface (see also Fig. 4)

Table 3

Summary of the EPMA results for the system Mo-N

\begin{tabular}{|c|c|c|}
\hline temperature & \multicolumn{2}{|c|}{ homogeneity range } \\
\hline$\left[{ }^{\circ} \mathbf{C}\right]$ & $\begin{array}{c}\text { concentration } \\
{[\text { at } \% \mathbf{N}]}\end{array}$ & $\begin{array}{c}\text { concentration } \\
{[\mathbf{a t} \% \mathbf{N}]}\end{array}$ \\
\hline 900 & 28.98 & 38.09 \\
\hline 1000 & 28.53 & 38.21 \\
\hline
\end{tabular}



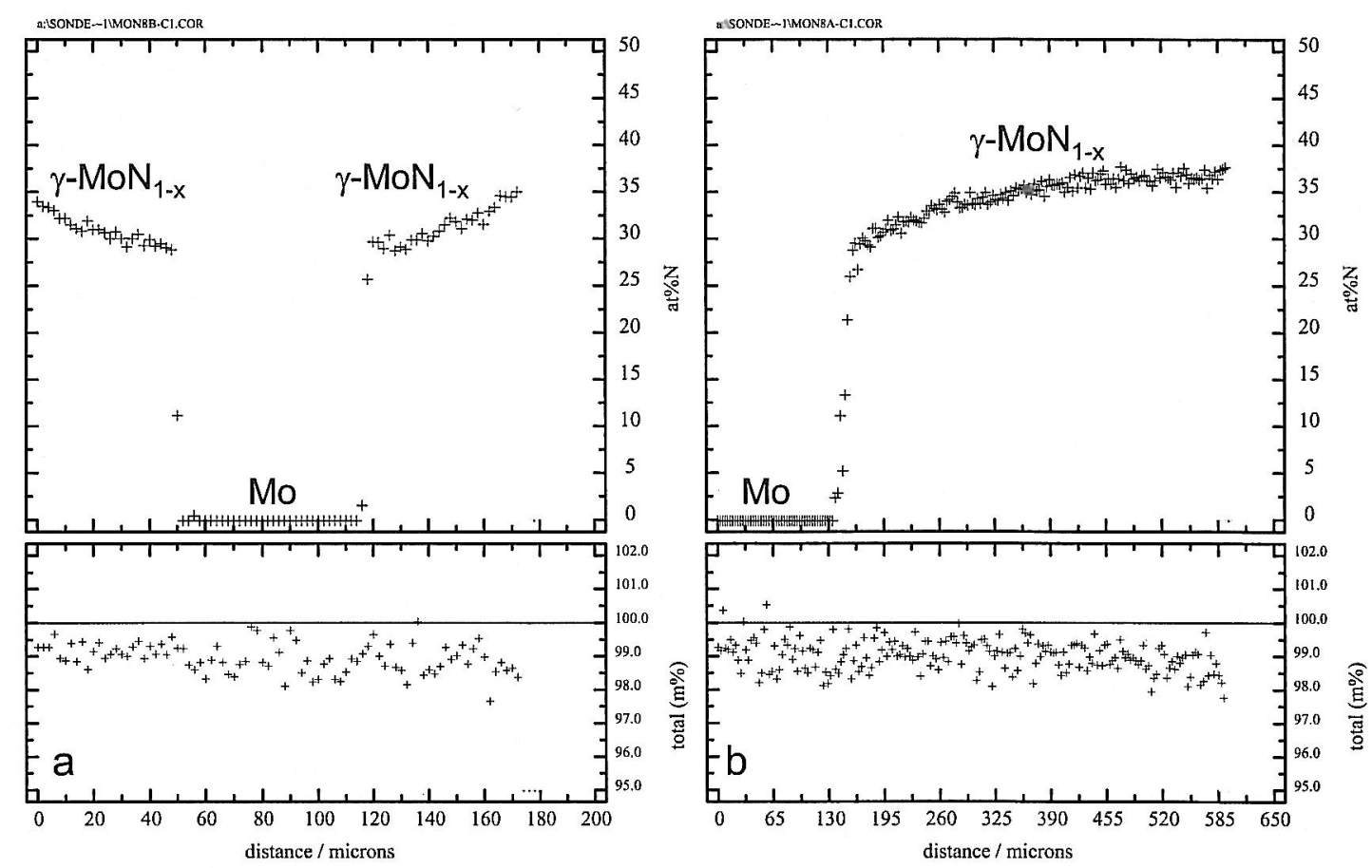

Fig.6

EPMA scans of Mo and N; a: scan along the diffusion path of $\mathrm{N}, \mathrm{b}$ : scan along the symmetry plane of the wedge-type sample

Also diffusion coefficients were calculated for these two temperatures. The homogeneity ranges and the calculated coefficients are shown in Table 4.

Table 4

Homogeneity ranges and diffusion coefficients for $900^{\circ} \mathrm{C}$ and $1000^{\circ} \mathrm{C}$

\begin{tabular}{|c|c|c|c|c|c|}
\hline temperature & $\mathrm{c}^{+} \mathrm{Mo}$ & $\begin{array}{l}\mathbf{c}^{-} \\
\gamma-\mathbf{M}\end{array}$ & $\begin{array}{c}c^{+} \\
N_{1-x}\end{array}$ & $\mathbf{D}_{\alpha}$ & $\mathbf{D}_{\gamma}$ \\
\hline$\left[{ }^{\circ} \mathrm{C}\right]$ & {$\left[\mathrm{molN} / \mathrm{cm}^{3}\right]$} & \multicolumn{2}{|c|}{$\frac{\gamma-\mathbf{M o N}_{1-\mathrm{x}}}{\left[\mathrm{molN} / \mathrm{cm}^{3}\right]}$} & {$\left[\mathrm{cm}^{2} / \mathrm{s}\right]$} & {$\left[\mathrm{cm}^{2} / \mathrm{s}\right]$} \\
\hline 1000 & 0.001 & 0.0373 & 0.0572 & average & average \\
\hline 1000 & 0.001 & 0.0369 & 0.0572 & $1.3 .10^{-9}$ & $2.14 .10^{-11}$ \\
\hline 900 & 0.001 & 0.0378 & 0.0569 & average & average \\
\hline 900 & 0.001 & 0.0378 & 0.0569 & $1.2( \pm 1) \cdot 10^{-9}$ & $7(+1,-2) \cdot 10^{-11}$ \\
\hline
\end{tabular}

The microhardness of a $\gamma-\mathrm{MoN}_{1-\mathrm{x}}$ diffusion layer obtained at $1000^{\circ} \mathrm{C}$ was measured as a function of the nitrogen content and compared with data from the literature [1] (see Fig. 7). It was found that there is an increase of the microhardness with increasing of the nitrogen content. The microhardness $\mathrm{H}_{\mathrm{v}}$ is $18.3 \mathrm{GPa}$ at $29.5 \mathrm{at} \% \mathrm{~N}$ and $21.4 \mathrm{GPa}$ at $35.5 \mathrm{at} \% \mathrm{~N}$. 


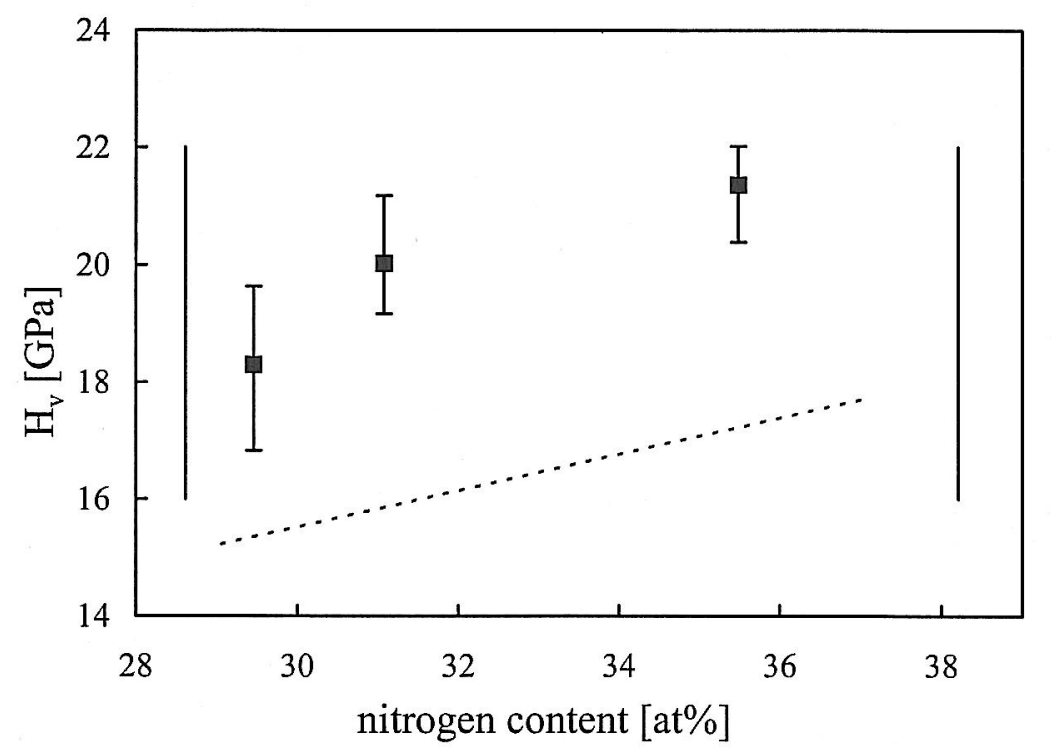

Fig. 7

Microhardness of the $\gamma-\mathrm{MoN}_{1-\mathrm{x}}$ layer grown at $1000^{\circ} \mathrm{C}$ as a function of the nitrogen content; vertical lines: homogeneity range of $\gamma-\mathrm{MoN}_{1-\mathrm{x}}$; dash-lined line: data of [1]

\section{CONCLUSIONS}

The in-diffusion of nitrogen into molybdenum sheet and powder via flowing ammonia as nitriding agent was investigated for various temperatures. In sheet samples a distinct and dense $\gamma-\mathrm{MoN}_{1-\mathrm{x}}$ layer formed above $600^{\circ} \mathrm{C}$. $\delta$-MoN also formed in both, powder and sheet samples, but it was too thin to be detected by metallography. Faint traces of $\beta-\mathrm{Mo}_{2} \mathrm{~N}$ were observed by XRD in powder samples. $\gamma-\mathrm{MoN}_{1-\mathrm{x}}$ can transform into $\beta-\mathrm{Mo}_{2} \mathrm{~N}$ and/or decompose upon cooling. This phenomena has to be studied in more detail (see also [4]).

The homogeneity range of $\gamma-\mathrm{MoN}_{1-\mathrm{x}}$ at around $900-1000^{\circ} \mathrm{C}$ was determinated to be $28.5-38.2 \mathrm{at} \% \mathrm{~N}$. The diffusivity of nitrogen in $\gamma-\mathrm{MoN}_{1-\mathrm{x}}$ is about $2.10^{-11} \mathrm{~cm}^{2} / \mathrm{s}$ at $1000^{\circ} \mathrm{C}$.

\section{ACKNOWLEDGEMENTS}

This work was supported by the French-Austrian Research Cooperation AMADEUS, project II.5.

\section{REFERENCES}

[1] M. Nagae, M. Nakanishi, J. Takada, Proc. of the Int. Plansee Sem. 1, 819 (1997)

[2] R. Marchand, F. Tessier \& F.J.DiSalvo, J. Mater. Chem. 9, 297 (1999)

[3] W. Lengauer, J. Cryst., Growth 87, 295 (1988)

[4] P. Ettmayer, Monatsh. Chem. 101, 127 (1970) 